\title{
REFERENCES TO COMMON LAW IN THE REASONS FOR JUDGMENTS BY POLISH COURTS
}

\author{
Grzegorz Maroń*
}

\begin{abstract}
The article presents the results of a study of the reasons for rulings of the Polish courts in terms of the presence in them of references to common law. The analysis of the title issue is mainly of a qualitative nature with descriptive, systematic, and explanatory features. The research has focused on determining the functions played by the references to common law in judgments and on recognizing the factors that rule or causally explain the practice of the courts referring to the given law system in their decisions. Some general regularities characterizing the discussed phenomenon have also been shown. Furthermore, quantitative findings on the scale, intensity, and dynamics of the references to common law in the reasons for judgments have been presented. Common law, which until now has been the subject of comparative studies of the Polish legal science, is increasingly drawing attention of the Polish courts as the law-applying bodies. Furthermore, the paper confirms the growing role of foreign law in the judicial decision-making process.
\end{abstract}

Key words: common law, Polish courts, reasons for judgments, comparative law method

* Ph.D. hab., Professor of University of Rzeszów, Department of Historical and Theoretical Legal Sciences, Faculty of Law, University of Rzeszów, e-mail: grzegorzmaron@op.pl, ORCID: 0000-0002-3861-9103. 


\section{INTRODUCTORY REMARKS}

Common law has repeatedly aroused the interest of Polish jurisprudence. Legal scientific considerations concerning it have usually been made in one of three contexts. Firstly, the domestic jurists presented in their studies the essence or specific features of the common law system ${ }^{1}$. Secondly, individual legal institutions both of substantive law and procedural law $^{3}$, have been discussed in the legal literature, in their form known to common law. Thirdly, a number of scientific publications deal with comparative law, however, stopping at presenting similarities and differences of a particular legal institution in Polish law, or more broadly in the civil law system, and in the legal systems of common law states ${ }^{4}$. A lot of attention, especially in the last two decades, has also been devoted to the place of the precedent institution in the judicial decisions of the states belonging to the continental law system, including Polish courts' decisions $s^{5}$ and the precedent nature of the sentences issued by the European Court of Human Rights and the Court of Justice of the European Union ${ }^{6}$.

On the other hand, the practice of referring to common law by Polish courts in reasons for judgments has not been studied yet by the legal doctrine. This paper presents and systematises the results of the conducted research on Polish judicial decisions for the presence of references to com-

1 E.g. Ireneusz Cezary Kamiński, Źródła prawa w systemie common law, Rejent 3 (2016): 9-27.

2 E.g. Monika Wałachowska, Macierzyństwo zastępcze w systemie common law, Państwo i Prawo 8 (2003): 97-107.

3 E.g. Grzegorz Maroń, Przysięga i ślubowanie świadka w anglosaskim porządku prawnym, Przegląd Sądowy 11/12 (2015): 150-168.

4 E.g. Bartosz Kołaczkowski, Kształtowanie się regulacji prawnych zgromadzeń w Polsce oraz w wybranych krajach o anglosaskiej tradycji prawnej, Warszawa: C.H. Beck, 2014.

5 See: Leszek Leszczyński, Bartosz Liżewski, Aadam Szot, ed., Precedens sądowy w polskim porządku prawnym, Warszawa: C.H. Beck, 2018; Anna Śledzińska-Simon, Mirosław Wyrzykowski, ed., Precedens w polskim systemie prawa, Warszawa 2010; Maciej Koszowski, Anglosaska doktryna precedensu. Porównanie z polską praktyką orzeczniczą, Warszawa: Warszawska Firma Wydawnicza, 2009.

6 E.g. Krzysztof Scheuring, Precedens w orzecznictwie Trybunału Sprawiedliwości Unii Europejskiej, Warszawa: Wolters Kluwer, 2010; Michał Balcerzak, Zagadnienie precedensu w prawie międzynarodowym praw człowieka, Toruń: Dom Organizatora, 2008. 
mon law in such judgements. The findings are mainly of a qualitative, and at the same time, descriptive nature.

The title issue is part of the broader problem of using foreign law in the judicial process. The use of comparative law in giving reasons for judicial decisions by national and international courts is gaining more and more significance in comparative legal scholarship ${ }^{7}$. Legal scholars' exploration of the topic of making references to foreign law in judgments has intensified especially in the last two decades. While it has long been the case that the courts, in giving reasons for judgments, made use of foreign legal acts and judicial decisions of foreign courts, it has never occurred on such a large scale as it happens today. Taking foreign law into account in judicial reasoning and making references to it in court decisions is part of a developing legal phenomenon of modern times known as "judicial globalization".

The place of foreign law in the judicial decision-making process is widely discussed in regards to the case law of the European Court of $\mathrm{Hu}$ man Rights and the Court of Justice of the European Union'. However, there are also numerous scientific papers on the application of foreign law by national - mainly constitutional - courts of different countries ${ }^{10}$ and

7 See Guy Canivet, Mads Andenas, Duncan Fairgrieve, ed., Comparative Law before the Courts, London: British Institute of International and Comparative Law, 2004; Mads Andenæs, Duncan Fairgrieve, ed., Courts and Comparative Law, Oxford: Oxford University Press, 2015.

8 E.g. Anne-Marie Slaughter, Judicial Globalization, Virginia Journal of International Law 40 (2000): 1103-1124. Compare: Elaine Mak, Judicial Decision-Making in a Globalised World. A Comparative Analysis of the Changing Practices of Western Highest Courts, Oxford: Hart Publishing, 2015.

9 See Christopher McCrudden, Using Comparative Reasoning in Human Rights Adjudication: The Court of Justice of the European Union and the European Court of Human Rights Compared, Cambridge Yearbook of European Legal Studies 15 (2012-2013): 383-415; Lee Faircloth Peoples, The Use of Foreign Law by the Advocates General of the Court of Justice of the European Communities, Syracuse Journal of International Law and Commerce 35 (2008): 219-273.

10 E.g. Jerome Waldron, Partly Laws Common to All Mankind: Foreign Law in American Courts, New Haven: Yale University Press, 2012; Tania Groppi, Marie-Claire Ponthoreau, ed., The Use of Foreign Precedents by Constitutional Judges, Oxford: Hart, 2013; Michal Bobek, Comparative Reasoning in European Supreme Courts, Oxford: Oxford University Press, 2013. Fryderyk Zoll, Argumentacja komparatystyczna w polskich są- 
different legal cultures ${ }^{11}$. The subject of this article falls under the given trend or field of contemporary comparative legal research.

The main intended addressee of the title study is the reader interested in comparative law's role in judicial decision-making process or/and concerned with the relationship and interactions between civil law and common law traditions. The study examined the practice of Polish courts resorting not to any foreign law but to common law. This research framework was dictated by the fact that common law for Polish courts is a law that belongs not only to another legal system but also to a separate type of legal culture. In other words, common law seems to be foreign law par excellence.

The purpose of the study is, in particular, to answer the following questions:

- What is the scale, intensity and dynamics of the cases where common law is referred to in the reasons for judgments by Polish courts with a division into particular types of courts?

- What types of references to common law can be distinguished in the Polish case law and what functions they perform in judicial argumentation?

- Can one see any regularities of the title practice of appealing to foreign law?

- What factors and processes affect and determine the practice of invoking common law as foreign law in Polish courts' decisions?

The research material has been the electronic database of judgments issued by common courts, administrative courts, the Supreme Court, and the Constitutional Court ${ }^{12}$, included in the LEX Legal Information Sys-

dach, In: Prawo obce w doktrynie prawa polskiego. Polska komparatystyka prawa, A. Wudarski, ed., Warszawa-Frankfurt nad Odrą: Stow. Notariuszy Rzeczypospolitej Polskiej, 2016, 119-132.

11 E.g. Kiichi Nishino, The Use of Foreign Law by Courts in Japan, In: The Use of Comparative Law by Courts, U. Drobnig, S. van Erp, ed., The Hague-London-Boston: Kluwer Law International, 1999, 223-230.

12 See Joanna Krzeminska-Vamvaka, "Courts as Comparatists: References to Foreign Law in the case-law of the Polish Constitutional Court", Jean Monnet Working Paper 5 (2012): 1-70. 
tem $^{13}$. The analysis has considered the judgments placed in the database until 30 June 2019.

The article covers the cases of references expressis verbis to common law in the reasons for judgments. The title concept of "common law" means "a type of law system present in the English culture" and "law made by courts of the English-speaking states in opposition to statute law". On the other hand, it was taken into account common law as "the total of the law system of individual English-speaking states" 14 insofar as references to the law of a particular country, e.g. American or Irish law, in the reasons for judgments are accompanied by the explicative assignment of a given national law into the common law type of legal system ${ }^{15}$.

This research and conceptual assumption is dictated by the court operationalization of the common law category in domestic judicial decisions. Speaking generally about common law, courts have in mind a generalized or averaged form of the legal system in English-speaking countries, within the meaning of the whole legal culture distinct from civil law, or case law seen as its key distinctive feature ${ }^{16}$. In referring by the courts to a particular legal institution proper for common law understood in this way, the secondary issue is the fact of possible differences between the shape of this institution in individual Anglo-Saxon states. Occasionally, it happens that a court would combine the term "the common law legal order" with the law of one, but not another, state of the common law culture. For example, the District Court (Sad Okregowy) in Lublin in one of its decisions distinguished "the common law legal system" from the American legal system, reserving implicite the given term only for the law in the United Kingdom ${ }^{17}$.

13 https://sip.lex.pl.

14 Krzysztof Łokuciejwski, Common law, In: Leksykon współczesnej teorii i filozofii prawa, J. Zajadło, ed., Warszawa: C.H. Beck, 2007, 34.

15 For a division into a specific legal system and a system type, see Grzegorz Maroń, Wstęp do prawoznawstwa, Rzeszów: Wydawnictwo Uniwersytetu Rzeszowskiego, 2011, 121.

16 Leszek Leszczyński talks about "the indisputable assumption that the category of court precedent is genetically and functionally related to the common law order". Leszek Leszczyński, Precedens w porządku prawa stanowionego. Ujęcia polskiej nauki prawa, In: L. Leszczyński, B. Liżewski, A. Szot, ed., Precedens..., 3.

17 Judgment of the District Court in Lublin of 4 October 2013, I C 87/07. 


\section{THE PRACTICE OF REFERRING TO COMMON LAW IN QUANTITATIVE TERMS}

References to common law ${ }^{18}$ have been found in a total of 156 decisions, including 78 judgments of common courts, 46 judgments of administrative courts, 19 decisions of the Constitutional Court and 13 decisions of the Supreme Court. Although in proportionate terms, the decisions containing references to English law system constitute a very small percentage of all judgments and orders, the references of this type are not sporadic in the domestic judicial decisions.

A clear intensification of appealing to common law can be seen in the last decade. About $81 \%$ of all the analysed references come from the years 2010-2019. A total of 24 rulings (over 15\%) with references to common law were issued in the first decade of this century, and only 5 in the 1990s (over 3\%). In case of the decisions of common courts and the Supreme Court, it is difficult to determine reliably the dynamics of referring to the precedent legal order in reasons for judgments, due to the fact that the database of judgments by both types of courts, used in the research, is highly incomplete, especially if older judgments are concerned. The problems in access to the research material, however, do not relate to the judicial decisions of the Constitutional Court and administrative courts, which allows for a reliable determination of the dynamics of reference to common law by these courts. Out of 46 administrative court rulings containing direct references to common law, 35 come from the years 2010-2019, and the remaining 11 from the years 2000-2009 (and more precisely, 2006-2009). Prior to 2006, references to common law were absent in decisions of administrative courts. The title issue is different in the chronological order in relation to the decisions of the Consti-

18 Common law in the aforementioned semantic framework is articulated by the Polish courts using over a dozen broadly synonymous terms: "common law", "prawo anglosaskie", "prawo precedensowe", "system prawa precedensowego", "system common law", "system prawa common law", "rodzina common law”, "prawo common law”, "prawo precedensowe (common law)”, "anglosaski porządek prawny (common law)”, "anglosaski system prawny", "system prawa anglosaskiego", "anglosaskie common law”, "system anglosaski”, "system precedensu”, "system precedensowy”, "kultura prawna państw anglosaskich", "model anglosaski", "model precedensowy". 
tutional Court. Out of 19 of its rulings containing references to common law, 9 come from the years 2010-2019, 8 from the years 2000-2009 and 2 from the 1990s. In three cases, such references were made in separate opinions related to Constitutional Court judgments.

\section{REFERENCES TO COMMON LAW}

\section{DENYING THE PRECEDENTIAL ROLE OF POLISH COURT JUDGMENTS}

Statistically, Polish courts most often refer in their reasons for judgments to common law legal order in the context of the institution of precedent. As a rule, the comments of the courts in this regard are a reaction to the claims of a party to the proceedings that the contested administrative decisions or first-instance judicial decisions are allegedly not complying with the previous court judgments issued in cases that are analogous in the party's belief. Courts questioning, from a procedural point of view, the relevance of the fact that the contested specific decision or judgment is inconsistent with other judgments made on the basis of a similar factual situation, usually do not go beyond mentioning that in the continental legal system, which includes Poland, precedents are not a source of law ${ }^{19}$. Additionally, the judicature has in mind precedents de jure, i.e. those of

19 Judgment of the District Court in Białystok of 14 December 2018, VIII Ka 594/18; judgment of the District Court in Rzeszów of 5 October 2018, VI GC 266/17; judgment of the Appellate Court in Szczecin of 19 July 2018, III AUa 756/17; judgment of the Regional Court in Bielsk Podlaski of 10 January 2018, VII W 418/17; judgment of the District Court in Siedlce of 23 June 2017, II Ka 357/17; Judgment of the District Court in Słupsk of 13 February 2017, I C 310/16; judgment of the Voivodship Administrative Court in Warsaw of 29 September 2016, V SA/Wa 3557/15; judgment of the District Court in Konin of 6 June 2016, I Ca 153/16; judgment of the Voivodship Administrative Court in Warsaw of 5 May 2016, V SA/Wa 2540/15; judgment of the Supreme Administrative Court of 15 May 2015, I OSK 986/14; judgment of the Voivodship Administrative Court in Poznań of 10 June 2014, II AKa 88/14; decision of the Supreme Administrative Court of 18 February 2014, II GZ 39/14; judgment of the Voivodship Administrative Court in Wrocław of 30 October 2013, I SA/Wr 1458/13; judgment of the Voivodship Administrative Court in Rzeszów of 22 October 2013, I SA/Rz 774/13; judgment of the Constitutional Tribunal of 14 February 2012, P 20/10; judgment of the Voivodship Administrative Court in Warsaw of 12 May 2010, II SA/Wa 330/10. 
a formally binding and normative nature ${ }^{20}$. Since the Polish legal system is not a case law system, "even judgments of the Supreme Court in some cases do not bind courts in other cases, even with similar facts" 21 , and therefore the courts are not obliged to follow "the theses expressed in previous judgments" 22 . The non-binding nature of earlier judgments for other courts has been justified by a closed system of law sources specified in Art. 87 of the Basic Law ${ }^{23}$. The court that has most often opposed the arguments of a party referring to previous judgments in similar cases, citing the fact that "in Poland there is no legal system based on precedents that is in force in the common law countries", has been the District Court in Gliwice ${ }^{24}$.

The common law legal order that is distinguished by the institution of precedent is compared not only with the rulings of Polish courts. The Voivodship Administrative Court in Warsaw, determining the status of judgments by the Court of Justice of the European Union, has repeatedly invoked the doctrinal view, according to which such rulings "cannot be attributed the strict de iure precedent nature, characteristic of the common law system" 25 .

20 Judgment of the Voivodship Administrative Court in Rzeszów of 20 October 2015, III AUa 79/15.

21 Judgment of the Regional Court in Olsztyn of 6 June 2014, IX W 1005/14.

22 Judgment of the Voivodship Administrative Court in Warsaw of 11 December 2012, IV SA/Wa 1427/12.

23 Judgment of the Regional Court for Warszawa-Mokotów of 24 July 2017, I C 536/17; judgment of the Regional Court in Olsztyn of 9 October 2015, II K 135/15; judgment of the Appellate Court in Poznań of 30 April 2013, III AUa 61/13.

24 See the sentences of this court of: 18 February 2019, V Ka 760/18; 4 February 2019, V Ka 752/18; 4 September 2017, V Ka 215/17; 23 October 2017, V Ka 415/17; 7 December 2017, V Ka 539/17; 7 December 2017, V Ka 566/17; 1 October 2018, V Ka 400/18; 25 October 2018, V Ka 449/18; 24 September 2018, V Ka 376/18; 12 July 2018, V Ka 223/18; 26 February 2018, V Ka 642/17; 22 November 2018, V Ka 316/18; 24 January 2019, V Ka 575/18; 18 June 2018, V Ka 569/17; 25 October 2018, V Ka 447/18; 2 August 2018, V Ka 243/18; 29 January 2019, V Ka 683/18; 11 March 2019, V Ka 576/18; 23 August 2018, V Ka 272/18; 4 October 2018, V Ka 339/18.

25 Judgments of the Voivodship Administrative Court in Warsaw of: 15 April 2013, III SA/Wa 159/13; 1 February 2013, III SA/Wa 1206/12; 14 May 2013, III SA/Wa 457/13; 10 June 2015, IV SA/Wa 2057/14; 5 April 2013, III SA/Wa 160/13; 9 April 2013, III SA/Wa 207/13; 15 April 2013, III SA/Wa 144/13; 12 April 2013, III SA/Wa 551/12. 
The description of the precedent institution presented in the reasons for some judgments raises reservations ${ }^{26}$. Even more serious objections arise from the way the courts respond to the arguments of a party to the proceedings referring to earlier judgments in similar $\mathrm{cases}^{27}$.

For example, the District Court in Szczecin stated that it would not refer to the judgment of the District Court in Elbląg, indicated by a party to the proceedings, "as Polish law does not apply case law, and therefore the judgments issued by other equivalent courts are not binding on the courts examining similar cases" ${ }^{28}$. This observation mistakenly suggests that in the common law countries a decision of one court becomes a precedent for another court at the same level in the structure of the justice administration system. This claim is wrong. In the common law system, the ruling of a given court is a precedent pro futuro on courts subordinate to the court which issued the ruling, and - although this is a more disputable issue - that court itself. The Regional Court (Sad Rejonowy) in Wałbrzych emphasized, however, that "there are no two identical cases and there is no case-law system in Poland ", and therefore the decision of the District Court in Legnica is not "binding in any way" on $\mathrm{it}^{29}$. This note, in turn, can suggest mistakenly that a precedent decision is in future applicable only to cases identical or same in terms of the facts and the legal issue as the original case, while in reality it may be applied to matters that are similar to a large extent to the case being the causal basis of the precedent.

The courts present wrongly a reference by a party to the proceedings to their earlier decision or a decision of another court as a call to make

26 In the judicial decisions there are also relevant observations on the nature of the case-law system. For example, the District Court in Wrocław corrects the mistaken belief, though popular in the public opinion, about the insignificant role of statutory law in the English legal order. As it notes, "even in the common law system, the application of positive law provisions is not conditioned on the existence of precedent court rulings in this matter, although they are far more important in the process of adjudication by the subsequent courts that examine the same matter”. Judgment of the District Court in Wrocław of 26 February 2019, XII C 1681/18.

27 For insufficient weight attached by courts to earlier court decisions, see: Hanna Filipczyk, Postulaty pewności prawa w wykładni operatywnej prawa podatkowego, Warszawa: Wolters Kluwer, 2013, 273-275.

28 Judgment of the District Court in Szczecin of 10 June 2015, VI U 378/15.

29 Judgment of the Regional Court in Wałbrzych of 11 February 2014, II K 861/13. 
this decision the legal grounds for a decision in the pending case ${ }^{30}$. For example, the Supreme Administrative Court in one of its rulings stated that the claim raised by the Head of the Tax Chamber that the first instance court did not refer to its another earlier judgment "was completely wrong, because the Court cannot be expected to refer to a judgment in another case as the legal grounds of the decision" ${ }^{11}$. The opinion of the Supreme Administrative Court presents unfair arguments as the "reference" to another judgment cannot be equated with making this judgment, the legal grounds for the decision. The parties do not expect that the court hearing their case will take a different judgement as a normative legal basis for its decision instead of the legal provisions, but, while pointing to other judgments, on the one hand, they refer to the argumentation provided in them, and on the other hand, they express their expectation of the decision consistency in terms of the coherence of operative legal interpretation results. In some circumstances, inconsistency of judicial decisions can be regarded as a violation of the party's right to a fair trial ${ }^{32}$. The position expressed in one of the judgments by the Appellate Court (Sad Apelacyjny) in Rzeszów should be highly approved, and it states that "although the Polish legal order is not based on case law (common law) and is a system of statutory law, yet, the issuance in the claimant's case of a judgement other than the decisions in the above earlier cases would be in conflict with the sense of social justice, which should also be respected by a court adjudicating under the binding legal order" 33 .

The categorical tone of some courts that disavow the utilitarian value of earlier rulings in analogous cases raises some objections. The District Court in Gliwice expressed its belief that "rulings of common courts in other similar cases... do not and cannot have any effect [emphasised by G.M.] on the outcome in this case. Each case should be examined individ-

30 Judgment of the Appellate Court in Poznań of 30 April 2013, III AUa 61/13.

31 Judgment of the Supreme Administrative Court of 17 December 2009, II FSK 1161/08.

32 Judgment of ECHR of 31 March 2015, app. no. 43807/06, S.C. Uzinexport S.A. v. Romania. Cf. judgment of ECHR of 11 April 2019, app. no. 11260/10, Mariyka Popova and Asen Popov v. Bulgaria.

33 Judgment of the Appellate Court in Rzeszów of 20 February 2019, III AUa 118/18. 
ually. The common law system is alien to the Polish criminal procedure"34. The problem of earlier rulings' significance in other cases is not exhausted in a binary alternative: the lack of any role and being the legal grounds for the decision. Quite rightly, several courts have emphasized that although "in Polish law, a sentence is binding only in a given case, i.e. the one in which it was passed", yet at the same time "it is of course possible to use its content in other proceedings" 35 or to look for an "interpretive hint" in it ${ }^{36}$.

The issue of best operationalization of arguments referring to other judgments in analogous cases, present in judicial decisions passed in a civil law country, goes beyond the scope of the study. It is enough here to indicate the complexity of it. Although it is not convincing to discredit a priori this type of arguments justifying it by the lack of a de iure precedent in the system of Polish law sources, yet, a court's reference to the decisions issued by other courts in similar cases as indicated by the parties to the current proceedings raises a number of questions and doubts ${ }^{37}$. Not without a good reason, the Supreme Administrative Court states that "the fact that a court of first instance does not refer to the content of a specific decision by another voivodship court does not mean that that court has not examined the essence of the case in a thorough, complete and proper manner. Particular court decisions, cited in support of specific positions, are only a reinforcement of their arguments. They are not the grounds for the decision. As the court of first instance rightly pointed out, regarding the content of decisions on individual interpretations of tax law, uniformity of judicial decisions, although a desirable feature, does not constitute a value in itself $f^{38}$. Each of the examined cases is a separate case and should

34 Judgment of the District Court in Gliwice of 8 March 2016, V Ka 55/16.

35 Judgment of the Voivodship Administrative Court in Łódź of 19 November 2015, I SA/Łd 888/15; I SA/Łd 889/15; judgment of the Voivodship Administrative Court in Olsztyn of 18 February 2016, I SA/Ol 755/15; judgment of the Voivodship Administrative Court in Warsaw of 15 February 2017, III SA/Wa 568/16, III SA/Wa 567/16.

36 Judgment of the Voivodship Administrative Court in Łódź of 20 April 2011, I SA/ Łd 238/11.

37 See: Leszek Leszczyński, Warunki korzystania z wcześniejszych decyzji sądowych w procesach stosowania prawa, In: L. Leszczyński, B. Liżewski, A. Szot, ed., Precedens..., 255-274.

38 Similarly: decision of the Voivodship Administrative Court in Lublin of 13 April 2016, III SA/Lu 438/16. 
be treated as such. It is impossible to refer to all rulings that have been issued in similar legal problems, and this is not the most important thing when examining a particular case.... A reference by a court of first instance to a decision of another, equivalent court would in fact be polemics with this decision, which would not have an impact on the result of the case in question" ${ }^{\text {"39. }}$.

It can be mentioned that it is also common for a party to the proceedings to use the claim that "Poland does not belong to the common law system" ${ }^{\prime 4}$ in order to base their criticism of quoting other previous decisions by a public administration authority or a court examining their case.

\section{REFERENCES TO COMMON LAW}

\section{HIGHLIGHTING DIFFERENCES BETWEEN POLISH AND ENGLISH LAW IN RELATION TO A SPECIFIC LEGAL ISSUE}

A significant part of references to common law in the Polish judicial decisions shows the differences between the domestic and common law legal orders. Usually, these disparities boil down to the fact that the particular solutions of precedent law system do not exist in Polish law at all, or functionally corresponding regulations in both orders show significant discrepancies. Sporadically, the courts stop at a laconic mere observation of "differences between the English legal system and the continental system" without their exemplification ${ }^{41}$.

As a rule, the differences signalled by the courts relate to a specific legal institution in the field of substantive or procedural law, less often in relation to systemic issues. An example of disparities from the second thematic

39 Judgment of the Supreme Administrative Court of 30 August 2017, II FSK 1703/15.

40 Judgment of the Voivodship Administrative Court in Bydgoszcz of 2 November 2010, II SA/Bd 941/10. Similarly: judgment of the Supreme Administrative Court of 25 June 2013, II OSK 757/12; judgment of the Supreme Administrative Court of 29 May 2013, I FSK 147/13; judgment of the Voivodship Administrative Court in Warsaw of 13 September 2012, I SA/Wa 2450/11; judgment of the Voivodship Administrative Court in Gliwice of 5 December 2007, IV SA/Gl 480/07.

41 Judgment of the Appellate Court in Szczecin of 5 December 2013, I ACa 745/13. 
area is the lack of legislative competence on the part of Polish courts, and whose decisions are not de iure precedents ${ }^{42}$.

On the basis of one of the cases, the Constitutional Court noted that the binding provisions in Poland regarding the employment of public officials "are substantially an expression of the career system, i.e. they differ from the solutions in the common law and Scandinavian countries in which a system of official positions has been adopted"43. In another judgment, the Court argued that under Art. $341 \$ 3$ of the Code of Criminal Procedure, the solution consisting in the possibility of postponing the court hearing regarding conditional discontinuance of proceedings in order to enable the accused to communicate with the injured party to repair the damages or to provide a compensation "is far from the process of negotiation and settlement in criminal matters (plea bargaining), known in the common law trial" $^{44}$. The Supreme Court, in turn, drew attention to "the need for demarcation between the institution of 'acquisition' (taking over), occurring in the FIDIC contract conditions, which has its origin in common law, and the 'receipt of works' (acceptance) within the meaning of the civil law"'45.

The Appellate Court in Katowice has highlighted the differences between Polish law and common law several times. It pointed out that "a common court cannot independently review the constitutionality of statutory provisions, as it is the case in the common law system (the institution of judicial review)" 46 ; "Polish law has not directly established a norm repealing the responsibility of a parliamentarian (a deputy and a senator) for violation of honour (good name) in parliamentary statements, as it

42 Judgment of the Voivodship Administrative Court in Bydgoszcz of 14 March 2018, I SA/Bd 45/18; judgment of the Supreme Administrative Court of 11 December 2009, II FSK 1204/08; judgment of the Supreme Administrative Court of 25 September 2007, II FSK 1017/06, II FSK 1018/06, II FSK 1019/06; judgment of the Voivodship Administrative Court in Wrocław of 16 December 2010, I SA/Wr 1233/10. Similarly: judgment of the Voivodship Administrative Court in Wrocław of 10 December 2010, I SA/Wr 1166/10, I SA/Wr 1165/10; judgment of the Voivodship Administrative Court in Wrocław of 29 November 2010, I SA/Wr 942/10.

43 Judgment of the Constitutional Tribunal of 17 November 2015, K 5/15.

44 Judgment of the Constitutional Tribunal of 16 May 2000, P 1/99.

45 Judgment of the Supreme Court of 13 September 2017, IV CSK 578/16; judgment of the Appellate Court in Katowice in Łódź of 27 July 2018, I ACa 1544/17.

46 Judgment of the Appellate Court in Katowice of 24 February 2011, II AKa 6/11. 
is the case in the common law systems, in which the absolute privilege of a parliamentarian has been established" 47 ; "in the Polish criminal trial, unlike the common law one, there is no... general rule, according to which any evidence obtained incorrectly becomes invalid immediately" ${ }^{3}$, or that the category of "domicile" in common law countries "expresses a person's relationship with a specific legal area or legal system and not with a specific place, as it is the case with the place of residence" 49 .

Several courts have stated in their rulings that, in contrast to the common law category of pure economic loss of use, in Polish civil law compensation is not due for the mere loss of the use possibility of a motor vehicle damaged or destroyed in a traffic accident. Only the consequence of deprivation of the use possibility of things may be pecuniary damage, e.g. caused by using a rented replacement $\mathrm{car}^{50}$.

Among other differences between Polish law and common law recorded in the judicial decisions one can mention, for example, the fully adversarial criminal trial in the Anglo-Saxon countries ${ }^{51}$, the admissibility of a bearer promissory note in common law countries ${ }^{52}$, or non-identity of bail as security on property and bail as a condition of release imposed by a court warrant ${ }^{53}$.

Some differences between Polish law and common law have been weakening over time, which is also noted by courts. For example, the $\mathrm{Su}-$ preme Court in one of its rulings mentioned that although lien type mortgage, known to the English legal order, does not appear in the Polish legal order, yet, "after the entry into force of the new Maritime Code on

47 Judgment of the Appellate Court in Cracow of 2 March 1994, I ACr 76/94.

48 Judgment of the Appellate Court in Katowice of 16 December 2004, II AKa 223/04.

49 Decision of the Appellate Court in Katowice of 5 June 2018, I ACz 423/18.

50 Judgment of the District Court in Częstochowa of 29 June 2016, V Ga 67/16; judgment of the Regional Court for Warszawa-Mokotów of 28 July 2016, XVI C 2904/15; judgment of the District Court in Kalisz of 19 October 2017, II Ca 352/17; judgment of the Appellate Court in Katowice in Warsaw of 15 April 2015, VI ACa 901/14.

51 Decision of the District Court of 10 March 2017, III Kop 2/17.

52 Judgment of the District Court in Koszalin of 11 October 2017, VII Ca 583/17.

53 Decision of the Appellate Court in Łódź of 24 July 1996, II AKz 275/96. On other differences see: judgment of the District Court in Warsaw of 20 July 2016, XXV C 1492/14; decision of the Regional Court in Włocławek of 9 November 2016, I Ns 2402/15; judgment of the Regional Court for Warszawa-Mokotów of 5 May 2015, XIV K 465/14. 
5 June 2002, Polish maritime law already incorporated some provisions allowing the parties to establish a contractual mortgage corresponding to a lien type mortgage" 54 . In another judgment, the same court noted that prima facie evidence "used in the common law systems" is "carefully adapted in Polish law, with an indication of its normative source as Art. 231 of the Civil Procedure Code" 55 .

Sometimes, when the courts signal the differences between civil law and common law, they oppose their exaggeration at the same time. They show that a different form of individual legal regulations in both types of legal systems does not have to be translated into significant disparities in the field of axiology and teleology. The Appellate Court in Krakow, on the one hand, called a "truism" "an indication that the procedural system of common law is different from the continental system". On the other hand, it stressed that although the common law system of court procedure is marked by the adversarial principle, almost in a pure form, yet, "despite the existing differences, that system implements the same goals and values as the Polish system of procedural law" 56 .

Rarely, the courts have indicated some differences in approach to a given issue in Polish law and common law, not so much reporting them, but they have confronted both legal orders, clearly raising and at the same time justifying the inadequacy of Anglo-Saxon solutions for the domestic justice system. On several occasions in the judicial decisions there have been instances of cutting off from the common law standards of freedom of expression in the context of a relationship between the right to information and freedom of expression and the right to privacy of public figures. The courts justified their distancing from the Anglo-Saxon solutions regarding freedom of expression by saying that "the scope of the right to freedom of expression must be considered taking into account the tradition

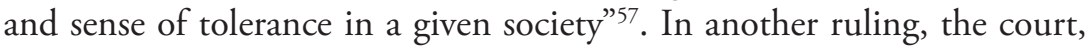

54 Decision of the Supreme Court of 28 February 2014, IV CSK 202/13.

55 Judgment of the Supreme Court of 11 April 2014, I CSK 291/13.

56 Decision of the Appellate Court in Cracow of 25 September 2015, I ACz 890/15.

57 Judgment of the Supreme Court of 11 October 2001, II CKN 559/99; judgment of the Supreme Court of 24 January 2008, I CSK 341/07; judgment of the Appellate Court in Gdańsk of 11 April 2014, I ACa 7/14; judgment of the Appellate Court in Warsaw of 29 April 2016, I ACa 665/15. 
rejecting the adequacy of the limits for freedom of expression adopted in the common law system for the operative legal interpretation of a provision prohibiting discriminatory content in media communications, stated that the assessment of the facts of the case "must be made taking into account the national level of sensitivity to the statement" 58 .

The Constitutional Court, justifying the constitutionality of the statutory regulation of the institution of legitim, argued that the solutions consisting in the use of "the criterion of equity defined in judicial decisions a casu ad casum..... and the criterion of closeness" are appropriate for the common law and not domestic legal order. It added that "an automatic transfer to the Polish order of legislation and law application of the concept of alimony protection of persons in a close relationship with the testator, known in the common law systems, always carries a risk of an excessive and disproportionate limitation of the constitutional basic right and of undermining trust in certainty and stability of law. Although these solutions undoubtedly allow adapting the decision to the actual conditions of each individual case, they, nevertheless, introduce an element of uncertainty and allow for varying degrees of interference in the freedom of making wills" 59 .

In turn, in the early 1990s, the Appellate Court in Katowice disagreed with following the common law jurisdictions on liability of the stock exchange. In its opinion, "a transfer of foreign legal solutions in the absence of comprehensive legal solutions for the so-called commodity exchanges, is not justified at the current stage of their development"60.

The characteristics of the differences in the compared legal orders, made in judicial decisions, sometimes stays controversial. The Voivodship Administrative Court in Warsaw, in one of the judgments, stated that "the obligation to respect the court decisions (orders) is accentuated especially in the common law legal systems, or the systems, in which a special attention is paid to the principle of the rule of law and the role

58 Judgment of the District Court in Warsaw of 14 August 2013, XX GC 757/12; judgment of the Appellate Court in Warsaw of 20 August 2014, VI ACa 1740/13.

59 Judgment of the Constitutional Tribunal of 25 July 2013, P 56/11.

60 Judgment of the Appellate Court in Katowice of 30 April 1993, I ACr 115/93. 
of independent courts in enforcing compliance with this rule"61. This quotation might suggest a contrario a smaller respect for court judgments and a smaller importance of the rule of law in the civil law culture. The court did not show, however, the evidence for making gradations of the weight of the rule of law because of the type of the legal culture.

Sporadically, the courts try to explain the source of differences in the regulation of certain issues in Polish (continental, European Union) law and in the common law systems. In one of the judgments the Constitutional Court assumed that Art. $42 \mathrm{sec} .1$ and 3 of the Constitution does not prejudge the fact that imposing of criminal (repressive) measures, and even more of other sanctions, can be awarded only by criminal courts. It pointed out that in the countries of the common law system no separate administrative courts had been established to adjudicate in matters of public law, but these cases had been subjected to the jurisdiction of common courts. At the same time, it explained that "the question of the type of court that decides in specific cases is a matter of systemic and organizational choices, not of substantive law" ${ }^{\prime 2}$.

\section{REFERENCES REVEALING SIMILARITIES}

IN THE POLISH AND COMMON LAW REGULATIONS

Statistically, the courts less often show similarities between Polish law and the common law legal order in approaching a particular legal principle or institution. Sometimes they compare common law not so much with domestic law but with the continental legal system, possibly with international law and European Union law. In the reasons for judgments, sometimes the degree of regulation convergence in the compared systems is also determined. In this context, the courts most often speak of "similarity", "referring to", "identity", "equivalence". In this way, they indirectly expose a certain universality of particular legal solutions.

${ }^{61}$ Judgment of the Voivodship Administrative Court in Warsaw of 19 September 2016, IV SA/Wa 1315/16.

62 Judgment of the Constitutional Tribunal of 4 July 2002, P 12/01. 
The Constitutional Court in one of the judgments found that the concept of objective civil and administrative responsibility "reminds the common law concept of strict liability", and therefore "it is not an absolute liability" ${ }^{63}$. In another ruling, it noted that in the light of the Court of Justice of the European Union's case law, "unnotified technical provisions may not be invoked against persons before authorities of the Member States, and in particular no obligations and penalties may be imposed on such persons. This is an expression of the Latin principle of nemo auditur, whose counterpart in common law is the doctrine of estoppel" ${ }^{4}$. In turn, Judge Wojciech Sokolewicz found the principle of democratic State of law as "a kind of equivalent of the common law principle of Rule of Law" ${ }^{65}$.

The Supreme Court in several of its rulings noted that "the Code of Civil Procedure does not provide for the general presumption of the exclusive nature of the national jurisdiction of the courts of the state indicated in a prorogation agreement, similarly to "the common law legal systems" ${ }^{6}$; "the common law institution of legal professional privilege can be identified with the defence secret of a lawyer under Polish law"67; the requirement provided for in Art. 79 sec. 1 point $3 \mathrm{~b}$ of the copyright act, regarding compensation for caused damage by payment of a sum of money corresponding to the double amount of the due remuneration, "takes in reality the form of a civil penalty known in common law as civil punity" 68 ; the institution of the will executor is also known in "the common law systems" 6 .

63 Judgment of the Constitutional Tribunal of 4 July 2002, P12/01. Cf. judgment of the Voivodship Administrative Court in Warsaw of 17 August 2011, VI SA/Wa 744/11; judgment of the Voivodship Administrative Court in Warsaw of 31 January 2013, VI SA/ Wa 2133/12; judgment of the Voivodship Administrative Court in Olsztyn of 7 February 2012, II SA/Ol 1020/11.

${ }^{64}$ Judgment of the Constitutional Tribunal of 11 March 2015, P 4/14.

65 Dissenting opinion of judge Wojciech Sokolewicz to judgment of the Constitutional Tribunal of 28 May 1997, K. 26/96.

66 Resolution of the Supreme Court of 7 September 2018, III CZP 38/18.

67 Decision of the Supreme Court of 2 June 2011, SDI 13/11.

68 Judgment of the Supreme Court of 10 November 2017, V CSK 41/14.

69 Decision of the Supreme Court of 6 August 2014, I CSK 482/13, I CSK 483/13. 
In the judicial decisions of the Supreme Court Polish law has not always been the reference point for common law. For example, in one of the judgments it was indicated that the Vienna Convention adopted "a common law-based guarantee model of contractual relationship", in which instances of non-performance and improper performance of the obligation are not separated ${ }^{70}$.

The common courts in their judgments have turned attention, among others, to the fact that "Art. 3531 of the Civil Code stipulates in the Polish legal system the principle of contract freedom, which is one of the basic principles of contract law, also established in other legal systems, both in continental law and common law" gree of social harmfulness (Art. $1 \S 2$ of the Criminal Code) leads to similar results as the common law abandonment of prosecution of such acts based on the principle of opportunism"72.

The similarities found in the judicial decisions between Polish (continental, European Union) law and common law have concerned not only individual substantive and procedural law regulations, but also rules of legal exegesis formed in the jurisprudence and judicial practice. On several occasions, the administrative courts have presented the principle of the priority of linguistic interpretation and the subsidiarity of the systemic and functional interpretation as being representative "on the grounds of our legal system ...as well as on the grounds of other legal systems belonging to the civil law and common law cultures"73.

Sometimes, the judicial decisions have pointed out the fact that a legal institution or practice of law application known to the Polish legal system dates back to the common law system or has been borrowed from it. Sometimes, at the same time, some differences have also been signalled between the domestic regulation and its common law prototype. For ex-

70 Judgment of the Supreme Court of 11 May 2007, V CSK 456/06.

71 Judgment of the District Court in Szczecin of 21 December 2015, VIII GC 458/14.

72 Decision of the District Court in Radom of 7 June 2018, II K 143/17.

73 Judgment of the Supreme Administrative Court of 15 May 2008, II OSK 548/07; judgment of the Supreme Administrative Court of 19 December 2008, I OSK 206/08; judgment of the Voivodship Administrative Court in Poznań of 24 September 2008, III SA/Po 348/08; judgment of the Voivodship Administrative Court in Poznań of 5 June 2009, III SA/Po 501/08. 
ample, the Constitutional Court drew attention to the "common law origins of the popular version of VAT", also adding that "the common law legal systems do not know the concept of 'appearance in legal acts', and therefore the recognition consequences of legal acts (in trade) as 'apparent'

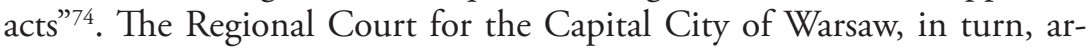
gued that in a situation where the grounds for a claim for damages sought from a counsel were a charge that due to their fault the party had been unsuccessful, it is necessary to examine whether the outcome of the court proceedings could have been different if the counsel had been performing properly their duties. A positive answer to this question does not undermine the validity of the court decision. "This concept, derived from the American common law system, is referred to as 'process in process' and the burden of proof is on the plaintiff'75.

The common law order has been shown as a reference point not only for Polish law, but also for foreign law of third countries and international law. For example, the Appellate Court in Warsaw noted that the Swedish legislation not providing for the division into limited liability companies and joint stock companies "is modelled on the common law system" ${ }^{\text {"7 }}$. In turn, the Constitutional Court found that the term "property" of Art. 1 of Protocol No. 1 of the European Convention on Human Rights "refers... to the common law institution of 'property' construed as ownership and not as proprietary right being ius in rem suam, a real right" ${ }^{\text {"77 }}$.

Sometimes the approach to the relationship between Polish law and common law in the context of a particular legal institution raises reservations. The District Court in Krakow stated that Art. 335 or 387 of the Code of Criminal Procedure "are an expression of reception by [Polish law], to some extent, of the common law concept of 'plea bargaining"'78. The court's use of the category "reception of law" is an abuse ${ }^{79}$.

There are also cases where the judgments of courts note some postulates, known to the legal scholarship, to reach for the adjudicatory stand-

74 Judgment of the Constitutional Tribunal of 5 November 2008, SK 79/06.

75 Judgment of the Regional Court for Warsaw of 3 June 2015, II C 1671/13.

76 Judgment of the Appellate Court in Warsaw of 29 June 2017, I ACa 585/16.

77 Judgment of the Constitutional Tribunal of 19 December 2002, K 33/02.

78 Judgment of the District Court in Cracow of 10 September 2018, IV 1Ka 83/2018.

79 Grzegorz Maroń, Wstęp..., 52. 
ards, developed in the system of common law, e.g. verification of material invasion of privacy under Art. 190a $\$ 1$ of the Penal Code by means of a reasonable bystander test ${ }^{80}$, or applying the definition of a dangerous product under Art. $4491 \$ 3$ of the Civil Code to a particular case by means of a consumer expectations test ${ }^{81}$.

In three judgments, the Voivodship Administrative Court in Poznań drew attention to the progressive and - in its opinion - inevitable convergence phenomenon of the civil law and common law systems determined by the process of European integration and the case law of the Court of Justice of the European Union ${ }^{82}$. In one of these judgments, the convergence phenomenon of both systems served the court to justify the judicial activism - literally referred to as "the creative approach" - consisting in issuing "precedent rulings praeter legem" when tax law is considered "bad" in a particular case ${ }^{83}$.

\section{REFERENCES TO COMMON LAW}

\section{AS PART OF A BROADER COMPARATIVE LAW ANALYSIS}

In the case of the judicial decisions of the Supreme Court, and in particular the Constitutional Court, exposing differences and /or similarities between Polish law and common law in relation to an issue has often been combined with the use by a court of the comparative method. Both courts then compared the domestic law with other legal orders, which also included the generalized common law legal order, or presented different models or standards for solving a particular issue, specific to these orders.

The Constitutional Court in a series of its rulings has pointed out, for example, that identical functions as deduction provided for in Polish

80 Judgment of the Regional Court in Łuków of 27 October 2017, II K 973/16.

81 Judgment of the District Court in Gliwice of 11 March 2015, III Ca 618/14.

82 Judgment of the Voivodship Administrative Court in Poznań of 1 June 2006, I SA/ Po 809/05; judgment of the Voivodship Administrative Court in Poznań of 16 February 2006, I SA/Po 826/04 (I SA/Po 827/04, I SA/Po 828/04).

83 Judgment of the Voivodship Administrative Court in Poznań of 25 January 2006, I SA/Po 2626/03. 
law "is fulfilled by the set-off institution known to the common law system" "4; a broad material scope of the right to court in the Constitution of the Republic of Poland is "an approach encountered... also in the common law countries" 85 ; "in common law, succession of the Treasury is referred to as escheat and is generally treated as exceptional" the common law states have adopted a system of solutions that "allows entrusting judicial functions to non-judicial bodies, i.e. various agencies, tribunals, arbitration bodies whose procedures provide for the possibility of appealing to a court, which is not, however, constitutionally obligatory" ${ }^{87}$; the common law model of the right to rectification "performs similar functions as in the continental law system, but it is based on self-regulatory acts such as codes of journalistic ethics and publisher agreements" 88 ; the common law system "does not know the legal institution of prescription" 89 .

In turn, the Supreme Court in its comparative study noted that in the common law system, the main centre of the debtor's basic activity under the COMI (Centre of main interests) is determined based on "the theory of the place of making strategic control decisions, assuming that the fundamental importance... has the way of organization of the enterprise's management functions (the mind of management)" In another ruling, the court pointed out that the possibility of limiting temporarily the impact of law interpretation is also known to "courts of common law states in the form of prospective overruling, i.e. changes in the current line of case law, with an effect for the future" 11 .

Much less often the comparative law method, covering references to foreign law, including common law, is used by the common and adminis-

84 Judgment of the Constitutional Tribunal of 31 July 2014, SK 28/13.

85 Judgment of the Constitutional Tribunal of 20 December 2017, SK 37/15.

86 Judgment of the Constitutional Tribunal of 4 September 2007, P 19/07.

87 Judgment of the Constitutional Tribunal of 13 March 1996, K 11/95.

88 Judgment of the Constitutional Tribunal of 1 December 2010, K 41/07.

89 Judgment of the Constitutional Tribunal of 23 May 2005, SK 44/04. Similarly: judgment of the Constitutional Tribunal of 25 May 2004, SK 44/03; judgment of the Constitutional Tribunal of 15 October 2008, P 32/06.

90 Judgment of the Supreme Court of 16 February 2011, II CSK 425/10.

91 Resolution of the Supreme Court of 28 January 2014, BSA I-4110-4/2013. 
trative courts. For example, the judgment of the Appellate Court in Warsaw, in which it was pointed out that "the institution of 'the crown witness' has been developed primarily in the countries belonging to the common law family, especially in the U.S." ${ }^{2}$

\section{GENERAL CHARACTERISTICS OF REFERENCES TO COMMON LAW IN THE REASONS FOR JUDGMENTS}

In most cases, references to the common law system, present in the reasons for judgments, have a form of not very extensive and synthetic mentions. This state of affairs should be assessed approvingly. In this way, the courts show awareness that the reasons for a judicial ruling are not a monograph or a scientific article in which a more extensive and multifaceted considerations on common law would be appropriate. In this respect, the judicature avoids unnecessary academic inquiry obscuring the procedural functions of the reasons for judgments.

This does not mean that in the judicial decisions there are no more thorough and extensive scrutiny of the common law system. Sometimes an in-depth study of various legal institutions, specific to common law, is dictated by the subject of the case examined by the court. For example, the District Court in Krakow recognizing a request of the public prosecutor's office on the extradition of a Polish citizen to the United States made an extensive analysis of resolving cases under the plea bargaining procedure, characteristic for the common law countries, with an indication of partial similarities and significant differences in relation to Polish law (Art. 335, 338a, 387 of the Code of Criminal Procedure) $)^{93}$.

It rarely happens that courts overlook the distinction between common law and the English legal doctrine, e.g., the Regional Court for Warszawa-Śródmieście in Warsaw, once described "legal harassment" as "a sociologically identified phenomenon known even to the common law

92 Judgment of the Appellate Court in Warsaw of 29 April 2005, II AKa 90/05.

93 Decision of the District Court in Cracow of 30 October 2015, III kop 14/15. 
jurisprudence"94, and on another occasion it called the same phenomenon as recognized under "common law"

Few references to common law in the reasons for judgments play the role of a means of linguistic expression. In one of the rulings of the Supreme Administrative Court and two judges of the Constitutional Court, in separate opinions, referred to the legal maxims derived from the "common law systems" or "the legal culture of the common law countries", i.e.

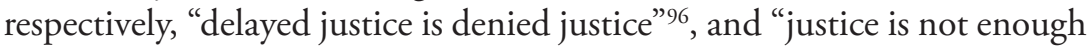
to be administered; people have to see it with their own eyes"97. It would be unauthorized, however, to assign them only an ornamental character, which consists in giving them a speech colour. In both cases, the cited legal maxims expressed some axiologically marked postulates on the judicial practice, namely, the need to examine cases without an undue delay and in an open court.

References to common law in the reasons for judicial decisions are the result of several intersecting agents. Firstly, a reference of a court to common law may be dictated by the subject or circumstances of the examined case with participation in it of a so-called "foreign element". In such an event, references to common law are expected and awaited, and their absence in the reasons for the judgment could be seen as a failure to hear the case comprehensively. For example, the Supreme Court in a case regarding a declaration of enforceability of a US court decision awarding,

94 Decisions of the Regional Court for Warszawa-Śródmieście of: 17 January 2019, XI W 4083/18; 18 December 2018, XI W 1805/18; 3 December 2018, XI W 4672/17; 29 November 2018, XI W 1660/18.

95 Judgment of the Regional Court for Warszawa-Śródmieście of 8 May 2019, XI W 484/19. Cf. judgment of the Appellate Court in Katowice of 24 October 2017, V ACa 38/17 and judgment of the Appellate Court in Poznań of 21 May 2015, III AUa $1453 / 14$. The courts correctly indicated that the individual names of insurance occurrences (trigger) originate from the "doctrine of common law system", and the principle of protection of legitimate expectations has been "taken to the Polish doctrine from the common law doctrine".

96 Decision of the Supreme Administrative Court of 16 October 2015, I OSK 1992/14.

${ }^{97}$ Dissenting opinion of judge Andrzej Rzepliński to decision of the Constitutional Tribunal of 7 January 2016, U 8/15; Dissenting opinion of judge Julia Przyłębska to judgment of the Constitutional Tribunal of 11 August 2016, K 39/16. 
inter alia, punitive damages in the amount of 4 million dollars, while explaining the essence of this type of compensation, known to common law countries, drew attention to its incompatibility with the compensatory functions of damages in Polish civil law ${ }^{98}$. In relation to a succession case, the Regional Court in Włocławek raised, in turn, that "the procedure of inheritance in the case of a person holding the citizenship of the United Kingdom is governed by the applicable law in a country that is the domicile (a country of permanent residence) of the deceased at the time of their death. According to common law, a person's real place of residence is less important" 9 .

Secondly, the court refers to common law in response to the arguments of a party to the proceedings who may either invoke the given legal order directly or implicitly, pointing some legal solutions known to that order, without its nominal designation. An example of a court referring to the common law as a result of the party's reasoning may be the case regarding punishment of a radio broadcaster by the President of the National Broadcasting Council for inclusion in the broadcast of a content discriminating on the grounds of nationality and sex. In the reasons for the ruling, the court wrote that "the view of the appellant regarding the common law system and the limits of freedom of expression adopted therein cannot be taken into account" ${ }^{100}$. Another exemplification of this situation is the reasons for the ruling, which dismissed the claim for compensation against the stock exchange for the actions of a stockbroker. The plaintiff referring to common law claimed that the broker accredited at the stock exchange is its representative, and therefore the stock exchange is responsible for the choice of contractors. The court did not agree with this claim, pointing out that "any comparison on the background of solutions of the stock exchange liability for brokers in common law cannot withstand criticism"101. An example of the court referring to common law in response to a party's implied reference to the precedent legal order are those numerous judg-

98 Decision of the Supreme Court of 11 October 2013, I CSK 697/12.

99 Decision of the Regional Court in Włocławek of 9 November 2016, I Ns 2402/15.

${ }^{100}$ Judgment of the District Court in Warsaw of 14 August 2013, XX GC 757/12; judgment of the Appellate Court in Warsaw of 20 August 2014, VI ACa 1740/13.

101 Judgment of the Appellate Court in Katowice of 30 April 1993, I ACr 115/93. 
ments in which the courts questioned the need to take into account other judgments issued in analogous cases, explaining that the Polish law system is not a case law system. Invoking by the court of common law was of the same provenance as it was to clarify that the concept of the so-called corporate veil, recalled by a party, is known to this law, but not to the Polish legal system ${ }^{102}$.

Thirdly, some references to common law in judgments are part of the typical comparative law analysis by the court. Precedent law system is then only one of the legal orders compared with the domestic law. Usually, common law in this context is mentioned by the Constitutional Court and the Supreme Court. It is beyond the scope of this paper to analyse the legitimacy issue of taking common law as a reference point for the court in its comparative reflection in a particular case ${ }^{103}$. Point 4 of this study provides examples of the use of common law by the courts as part of comparative and legal inquiry.

Fourthly, references to common law in the reasons for judgments may be contingent in nature in the sense that they are a certain unnecessary addition to the court's arguments which are not casually related to the claims of a party to the proceedings, the circumstances of the case itself, and they do not fall within a broader comparative reasoning. Their unnecessity does not mean redundancy, objectlessness or uselessness. A court mentions common law because in a particular case it recognizes that such a mention is useful for its argumentation, i.e. it contributes to the fulfilment of the clarification (explanatory) function and/or the persuasive function for the reasons for the judgment. However, this does not change the fact that the reference to the common law is of a subsidiary nature. References of this type are diverse thematically and functionally. For example, courts justifying the need to be guided by the meaning of a legal norm established in the linguistic interpretation noticed that the priority of the linguistic interpretation is also known to "other legal systems belonging to the civil law and common law cultures"104.

${ }^{102}$ Judgment of the District Court in Nowy Sącz of 16 January 2014, III Ca 785/13.

${ }^{103}$ Piotr Chybalski, Wykładnia komparatystyczna w orzecznictwie konstytucyjnym zarys problemu, Temidum 2 (2019), 36.

104 See note No. 67. 
In many cases of references to common law in judicial decisions, one can trace elements of the discursive style of giving reasons for the judgments. In the legal scholarship discursive justification is presented as associated with "an indication of different possible decisions of individual particular issues, quoting arguments in favour of each of the possible decisions, a substantiated choice of the optimum decision"105. A judge uses "the widest range of interpretative arguments"106, formulates "arguments for and against in relation to competing alternative interpretative solutions" 107 . In this way they communicate "that they have a room for manoeuvres and that they have a choice among several possibilities, all of which 'can be defended' against the background of the text which has served them as the basis for the decision"108.

References to common law are part of the discursive style of providing reasons for judgments especially if they are a reaction to some arguments of the parties to the proceedings or are a part of a comparative law analysis. In the first case, the court, wanting to strengthen the persuasive power of its own reasoning and the issued decision, refers to each of the parties' claims. The degree of discursiveness depends on how carefully and comprehensively the court addresses the party's arguments. This discursiveness is limited, whenever the court, for example, stops only at a laconic observation about the incompatibility of the party's arguments to the circumstances of the examined case, because of the fact that the solutions relied on by the party are representative of common law, but they do not fit the realities of Polish law.

Even a greater potential for discursiveness of the reasons for judgments is associated with comparative law considerations of the court. The discursive style is not coincidently attributed in the legal science to the judicial decisions of the Supreme Court and the Constitutional Court, i.e.

${ }^{105}$ Maciej Zieliński, Wykładnia prawa. Zasady, reguły, wskazówki, Warszawa: LexisNexis, 2010, 264-65.

${ }^{106}$ Leszek Leszczyński, Uzasadnienie sądowej decyzji stosowania prawa a walidacyjno-derywacyjne ujęcie wykładni operatywnej, In: M. Grochowski, I. Rzucidło-Grochowska, ed., Uzasadnienia decyzji stosowania prawa, Warszawa: Wolters Kluwer, 2015.

107 Krzysztof Płeszka, Wykładnia rozszerzająca, Warszawa: Wolters Kluwer, 2010, 167.

108 Ewa Łętowska, Pozaprocesowe znaczenie uzasadnienia sądowego, Państwo i Prawo 5 (1997): 4. 
the courts, which most often reach for the comparative method ${ }^{109}$. However, using this method per se does not guarantee the discursive nature of the reasons for the judgment. It depends on the representativeness of the sources selected for the comparative analysis and basing on these sources in their adequate (true) form, as well as on the reliability of the analysis itself in the sense of, above all, an objective statement of reasons for or against the solutions known to foreign law.

\section{SUMMARY}

References of Polish courts to common law in judgments are part or an exemplification of at least several court processes that mark the form of the domestic legal order, including its judicial decisions. Firstly, in the described judicial practice, one can detect some signs of formulating reasons for decisions with some elements of the discursive style with which is also correlated with the issue of legal argumentation or judicial rhetoric. Secondly, this practice is to some extent related to the aforementioned process of convergence of the civil law and common law cultures, although estimating the scale of the convergence phenomenon itself is an issue highly evaluative. Thirdly, the presence of the institution of precedent in the citizens' legal consciousness is translated into reference by them, as parties to the proceedings, to earlier judgments, which in turn forces courts to remind that this institution - in the sense of the de iure precedent - is governed by common law. Fourthly, in referring to common law by courts, one can see, if not necessarily the application of the classically understood comparative law method, at least a rudimentary form of comparative reasoning considering foreign law. Finally, along with the progressing processes of Europeanization and globalization, there are more and more court cases with the participation of the so-called "foreign element" whose examination with consideration of common law becomes justified and even necessary due to the subject matter of the case or the parties involved.

109 Jerzy Leszczyński, O charakterze dyrektyw wykładni prawa, Państwo i Prawo 3 (2007): 41; Stanisław Czepita, Łukasz Pohl, Glosa do uchwały SN z dnia 29 października 2012 r., I KZP 12/12, Państwo i Prawo 10 (2014): 132-140. 
A clear intensification of references to common law in the reasons for judicial decisions in the last decade, especially in the judgements of administrative courts and common courts, shows the fact that the distance between the orders of positive law and case law is not as great as it might seem prima facie. On the other hand, however, it would be an abuse and exaggeration, only because of the above-analysed practice of courts, to ignore still significant differences and distinctions between the civil law culture that is characteristic of Poland, and the common law culture.

Until recently, common law in Poland has been mainly of interest to domestic jurisprudence. The study of the judgments shows that the given legal system draws increasing attention and is the subject of an analysis and interpretation of Polish courts. At the same time, the article confirms the growing role of foreign law in the judicial decision-making process in European countries. Common law, being outside the Polish legal system, cannot act as the normative basis for a judgment, but it is a useful comparative reference point for judicial argumentation.

\section{REFERENCES}

Andenæs Mads, Fairgrieve Duncan, ed., 2015. Courts and Comparative Law, Oxford: Oxford University Press.

Balcerzak Michał. 2008. Zagadnienie precedensu w prawie międzynarodowym praw człowieka, Toruń: Dom Organizatora.

Bobek Michał. 2013. Comparative Reasoning in European Supreme Courts, Oxford: Oxford University Press.

Chybalski Piotr. 2019. Wykładnia komparatystyczna w orzecznictwie konstytucyjnym - zarys problemu, Temidum 2: 33-36.

Canivet Guy, Andenas Mads, Fairgrieve Duncan, ed., 2004. Comparative Law before the Courts, London: British Institute of International and Comparative Law.

Czepita Stanisław, Pohl Łukasz. 2014. Glosa do uchwały SN z dnia 29 października 2012 r., I KZP 12/12, Państwo i Prawo 10: 132-140.

Faircloth Peoples Lee. 2008. The Use of Foreign Law by the Advocates General of the Court of Justice of the European Communities, Syracuse Journal of International Law and Commerce 35: 219-273. 
Filipczyk Hanna. 2013. Postulaty pewności prawa w wykładni operatywnej prawa podatkowego, Warszawa: Wolters Kluwer.

Groppi Tania, Ponthoreau Marie-Claire, ed., 2013. The Use of Foreign Precedents by Constitutional Judges, Oxford: Hart.

Kamiński Ireneusz Cezary. 2016. Źródła prawa w systemie common law, Rejent 3: 9-27.

Kołaczkowski Bartosz. 2014. Kształtowanie się regulacji prawnych zgromadzeń w Polsce oraz w wybranych krajach o anglosaskiej tradycji prawnej, Warszawa: C.H. Beck.

Koszowski Maciej. 2009. Anglosaska doktryna precedensu. Porównanie z polską praktyką orzeczniczą, Warszawa: Warszawska Firma Wydawnicza.

Krzeminska-Vamvaka Joanna. 2012. Courts as Comparatists: References to Foreign Law in the Case-Law of the Polish Constitutional Court, Jean Monnet Working Paper 5: 1-70.

Leszczyński Jerzy. 2007. O charakterze dyrektyw wykładni prawa, Państwo i Prawo 3: $28-44$.

Leszczyński Leszek, Warunki korzystania z wcześniejszych decyzji sądowych w procesach stosowania prawa, In: Precedens sądowy w polskim porządku prawnym, Leszek Leszczyński, Bartosz Liżewski, Adam Szot, ed., Warszawa: C.H. Beck, 255-274.

Leszczyński Leszek, Precedens w porządku prawa stanowionego. Ujęcia polskiej nauki prawa, In: Precedens sądowy w polskim porządku prawnym, Leszek Leszczyński, Bartosz Liżewski, Adam Szot, ed., Warszawa: C.H. Beck, 3-20. Leszczyński Leszek. 2015. Uzasadnienie sądowej decyzji stosowania prawa a walidacyjno-derywacyjne ujęcie wykładni operatywnej, In: Uzasadnienia decyzji stosowania prawa, M. Grochowski, I. Rzucidło-Grochowska, ed., Warszawa: Wolters Kluwer, 87-101.

Łętowska Ewa. 1997. Pozaprocesowe znaczenie uzasadnienia sądowego, Państwo i Prawo 5: 3-17.

Łokuciejwski Krzysztof. 2007. Common law, In: Leksykon współczesnej teorii i filozofii prawa, J. Zajadło, ed., Warszawa: C.H. Beck, 34-36.

Elaine Mak. 2015. Judicial Decision-Making in a Globalised World. A Comparative Analysis of the Changing Practices of Western Highest Courts, Oxford: Hart Publishing.

Maroń Grzegorz. 2015. Przysięga i ślubowanie świadka w anglosaskim porządku prawnym, Przegląd Sądowy 11/12: 150-168.

Maroń Grzegorz. 2011. Wstęp do prawoznawstwa, Rzeszów: Wydawnictwo Uniwersytetu Rzeszowskiego. 
McCrudden Christopher. 2012/2013. Using Comparative Reasoning in Human Rights Adjudication: The Court of Justice of the European Union and the European Court of Human Rights Compared, Cambridge Yearbook of European Legal Studies 15: 383-415.

Nishino Kiichi. 1999. The Use of Foreign Law by Courts in Japan, In: The Use of Comparative Law by Courts, U. Drobnig, S. van Erp, ed., The Hague-London-Boston: Kluwer Law International, 223-230.

Płeszka Krzysztof. 2010. Wykładnia rozszerzająca, Warszawa: Wolters Kluwer.

Scheuring Krzysztof. 2010. Precedens w orzecznictwie Trybunału Sprawiedliwości Unii Europejskiej, Warszawa: Wolters Kluwer.

Slaughter Anne-Marie. 2000. Judicial Globalization, Virginia Journal of International Law 40: 1103-1124.

Śledzińska-Simon Anna, Wyrzykowski Mirosław, ed., 2010. Precedens w polskim systemie prawa, Warszawa.

Waldron Jerome. 2012. 'Partly Laws Common to All Mankind': Foreign Law in American Courts, New Haven: Yale University Press.

Wałachowska Monika. 2003. Macierzyństwo zastępcze w systemie common law, Państwo i Prawo 8: 97-107.

Zieliński Maciej. 2010. Wykładnia prawa. Zasady, reguły, wskazówki, Warszawa: LexisNexis.

Zoll Fryderyk. 2016. Argumentacja komparatystyczna w polskich sądach, In: Prawo obce w doktrynie prawa polskiego. Polska komparatystyka prawa, A. Wudarski, ed., Warszawa-Frankfurt nad Odrą: Stow. Notariuszy Rzeczypospolitej Polskiej, 119-132. 
